\title{
Tomato Juice and Dragon Fruit Juice to Reduce Blood Sugar Level
}

\author{
$1^{\text {st }}$ Fitri Suciana \\ Department of Nursing \\ STIKES Muhammadiyah Klaten \\ Central Java, Indonesia \\ *fitrisuciana@stikesmukla.ac.id
}

\author{
$2^{\text {nd }}$ Saifudin Zukhri \\ Department of Nursing \\ STIKES Muhammadiyah Klaten \\ Central Java, Indonesia
}

\author{
$3^{\text {rd }}$ Cahyo Pramono \\ Department of Nursing \\ STIKES Muhammadiyah Klaten \\ Central Java, Indonesia
}

\begin{abstract}
Diabetes Mellitus non communicable disease that is included in the top ten disease that cause death. The higest prevalence of people with diabetes melitus type 2 that occurs as aresult of unhealthy daily lifestyle. Diabetes Melitus can improve the Quality of Life by managing Diabetes Melitus which consist of education, diet, physical activity, medication and monitoring of blood sugar levels. Diet using tomato juice and dragon fruit juice to reduce blood sugar levels. The method with used one group pretest and posttest with control group. the ssample of this research is $\mathbf{4 8}$ samples, consist of $\mathbf{1 6}$ samples with control group, 16 samples with juice tomato, 16 samples with dragon fruit juice. the instrument in this study used the observation checklist giving juice. juice is given once a day for two weeks. The method using statistical test independent $t$ test. Analysis of the difference test between the control group and given tomato juice had no effect on the difference in decrease in blood sugar levels with $P$ value of 0.363 , and the analysisi of test difference between the control group. Dragon fruit juice had no effect on the difference in decreasing blood sugar levels with a $P$ value of 0.061 . The summary tomato juice and dragon fuit juice does not have a significant effect in reducing sugar levels.
\end{abstract}

Keywords-Tomato Juice, Dragon Fruit Juice, Blood Sugar

\section{INTRODUCTION}

Non communicable disease have become a public health problem. One non communicable disease that has a lot of attention is Diabetes Mellitus. Diabetes Mellitus is a group disorders characterized by an increase in blood glucose levels or hyperglycemia. Glucose is formed in the liver from food consumed. Insulin is a hormone produced by the pancreas, and the function is control glucose levels in the blood by regulating the product and storage [1].

In Indonesia, Diabetes Mellitus is a serious threat to health development, because it can cause blindness, kidney failure, diabetic foot (gangrene) and it must be amputated, heart disease and stroke. Diabetes mellitus is ranked $6^{\text {th }}$ as a cause of death. About 1.3 million people die and $4 \%$ die before the age of $70^{\text {th }}$ because diabetes mellitus. In 2030 diabetes is estimated to rank $7^{\text {th }}$ cause of world death. In Indonesia it is estimated that in 2030 there will be 21.3 million people with Diabetes Mellitus. Data in The International Diabetes Federation (IDF) that more than 371 million people in the worl aged 20-79 years have a diabetes. While Indonesia is the $7^{\text {th }}$ country with the highest prevalence of diabetes, after China, India, USA, Brazil , rusiia and Mexico [2]. Riskesdas in 2018 showed an increase in the incidence of Diabetes Mellitus from $6.9 \%$ in 2013 to $8.5 \%$ in 2018, while the prevalence of Diabetes Mellitus in Central Java was $2.1 \%$

The prevalence of Diabetes Melitus which tends to increase makes many reaserchers interested in developing anti diabetes drugs. Oral hypoglycemic drugs (OHO) are the main line treatment for type 2 Diabetes Mellitus. These oral hypoglycemic drugs have also been effective in reducing high blood sugar levels, but complications caused by diabetes. It's not well prevented so efforts are still needed to find new drugs with anti diabetic physiological abilities that are right target, safe and easily affordable or economically [3]

Dragon fruit weight 200 grams given for 10 days can reduce blood sugar levels, measurements were taken on day 0 and day 11 in the control group and intervention group. Based on the results of this study it was found that there were differences in average blood glucose levels in the control group and the intervention group after being given a red drgaon fruit. The difference in blood glucose levels is possible because in the intervention group respondents were given a red dragon fruit that can provide hypoglycemic effects, while the control group was not given any intervention [4]. Vitamin C contained in dragon fruit can help lower blood sugar levels, and can reduce the complications due to diabetes in blood vessels. a daily intake of vitamin C $1000 \mathrm{mg}$ in people with diabetes mellitus can result in a significant decrease in blood sugar levels so that blood sugar balance is better maintained in the body [5]

Juice therapy that can be used in treating diabetes mellitus is using tomatoes Tomatoe are done of the fruits or some are categorizing these tomatoes as vegetables. Tomatoes contain vitamin A for eye health, vitamin $\mathrm{C}$ for cell regeneration and the immune system and vitamin $\mathrm{K}$ for bone health. Tomatoes also contain lycopene which is an atntioxidant to fight free radicals and reduce to blood sugar levels [6] . Food intake from tomato products containing lycopene has been shown to reduce the risk of chronic diseases such as preventing cardiovaskuler disease, diabetes, osteoporosis, infertility, and cancer [7]. These 
effects are related to the antioxidant activity of tomatoes. Lycopene acts has an influence in reducing the risk of various chronic diseases including cancer and can be increases in the body if tomatoes are processed into juice, sauce and others [8]

\section{METHOD}

This study use a pre experimental method with the onegroup pretes and post test design approach by used a control group as a comparison [9]. Sampling using purposive sampling technique and a total sample of 48 respondents. 16 respondents with a tomatoes juice, 16 respondents with a dragon fruit juice and 16 respondents are control groups. Inclusion criteria are 45-60 years old, diagnose with Diabetes Melitus more than 1 year, GDS more than 150 $\mathrm{mg} / \mathrm{dl}$ and willing to become respondents. The instruments used check list observation and glucometer. Juice was given once a day for 2 week. Analysis used paired t test to determine differences in blood sugar levels before and after the intervention.

\section{RESULTS AND DISCUSS}

TABLE I. BLOOD SUGAR LEVELS WITH TOMATO JUICE INTERVENTION (N=32)

\begin{tabular}{|c|c|c|c|c|c|c|c|c|c|}
\hline & \multicolumn{2}{|l|}{ Pretest } & \multicolumn{4}{l|}{ Posttest } & Average \\
& min & Max & Mean & SD & Min & Max & Mean & SD & \\
& & & & & & & & & \\
\hline Tomato & 162 & 181 & 169.31 & 5.449 & 140 & 156 & 148.81 & 4.833 & 20.50 \\
& & & & & & & & & \\
\hline Control & 160 & 172 & 166.13 & 4.064 & 136 & 160 & 146.75 & 6.708 & 19.38 \\
\hline
\end{tabular}

Blood sugar levels in diabetics can decrease due to pharmacological and non-pharmacological therapy. Management for patients with diabetes mellitus according to them is non pharmacological therapy which includes management of diet, exercise, monitoring blood sugar levels, health education and pharmacological therapy, namely pharmacological drugs for diabetes mellitus [1].

TABLE II. BLOOD SUGAR LEVELS BEFORE AND AFTER DRINKING TOMATO JUICE (N=32)

\begin{tabular}{|l|l|l|l|l|}
\hline Group & Perlakuan & N & Mean & p value \\
\hline Tomato & Pretes & 16 & 169,31 & 0,000 \\
Fruit & Posttest & & 148,81 & \\
\hline Control & Pretes & 16 & 166,13 & 0,000 \\
& Posttest & & 146,75 & \\
\hline
\end{tabular}

The results of this study can be reduce blood sugar levels. This research was conducted for 10 days every day and respondents still consume insulin. Therapy modalities or interventions that can be used by patients to improve his health and has become part of nursing orders [10].Tomato

juice is a combination of nutrition and pharmacy Tomatoes contain vitamin A for eye health, vitamin $\mathrm{C}$ for cell and immune system, vitamin $\mathrm{K}$ for bone health. Tomatoes also contain lycopene which is a antioxidant to fight free radicals and reduce blood sugar levels [8]

TABLE III. ANALYSIS OF DIFFERENCES IN BLOOD SUGAR LEVELS IN CLIENTS WITH THE DIABETES MELLITUS INTERVENTION GROUP AND THE CONTROL GROUP $(\mathrm{N}=32)$

\begin{tabular}{|l|l|l|l|l|}
\hline & $\mathrm{N}$ & Mean & $\mathrm{SD}$ & $\mathrm{P}$ value \\
\hline Tomato juice & 16 & 20.50 & 2.852 & 0.363 \\
\hline Control & 16 & 19.38 & 3.948 & \\
\hline
\end{tabular}

The results that there is no difference in blood sugar levels in respondents who drink tomato juice with insulin compared to respondents who drink consumption insulin. This study control group consume anti diabetic sugar so blood sugar levels also a decrease, the same as the group of respondents who were treated with consumption of tomato juice. this study proves that blood sugar levels can go down if given tomato juice. The results of other studies indicate that the tomato paste affects the blood sugar levels of diabetes mice. The most effective amount of tomato paste to reduce blood sugar levels. In $62 \mathrm{mg}$ tomato paste $40 \mathrm{mg}$ lycopene) with percentage decrease in blood sugar levels reaching $75.60 \%$. In pure lycopene content is $135 \mathrm{mg} / 100 \mathrm{~g}$, vitamin C $37.84 \mathrm{mg} / 100 \mathrm{~g}$, antioxindant $446.76 \%$, water content $94.51 \%$, whereas in paste lycopene content is 169 $\mathrm{mg} / 100 \mathrm{~g}$, vitamin C $4.58 \mathrm{mg} / 100 \mathrm{~g}$, antioxidant 386.61, water content $92.86 \%$ and yield $66.15 \%$ [7]. Tomatoes as a non-pharmacological therapy for diabetes Mellitus is one type of fiber food. Fiber in tomatoes is insoluble dietary fiber, namely hemicellulose. Lycopene can also increase insulin concentration, decrease $\mathrm{H} 2 \mathrm{O} 2$ so that can function as an antidiabetic Lycopene content in tomatoes can reduce oxidative damage to cellular DNA and reduce fat peroxidation caused by diabetes [11].Fiber can slow the absorption of glucose from the small intestine so that it can reduce bood glucose levels. insoluble fiber reduces the process of gluconeogenesis which affects the increase in insulin secretion so that it can reduce 47 increases in glucose levels [12]. Non pharmalogical management is aimed at prevention and management healthy living. 
Prevention of diabetes mellitus consist of healthy nutrition, weight control, adequate sleep, exercise or physical therapy, fruit juice therapy, monitoring blood sugar, relaxed atmosphere and stop smoking[13].Type 2 management Diabetes Mellitus consists of a healthy lifestyle, then if with healthy lifestyle and blood glucose monotherapy has not been controlled, then given a combination of two drugs. Combination therapy must be chosen two drugs which work differently, for example sulfonylureas and metformin[14]

TABLE IV. BLOOD SUGAR LEVELS IN DIABETES MELLITUS ( $\mathrm{N}=32)$

\begin{tabular}{|c|c|c|c|c|c|c|c|c|c|}
\hline \multirow[t]{2}{*}{ Group } & \multicolumn{4}{|c|}{ Pretest } & \multicolumn{4}{|c|}{ Posttest } & \multirow[t]{2}{*}{ Average } \\
\hline & Min & Max & Mean & SD & Min & Max & Mean & SD & \\
\hline Dragon & 165 & 175 & 170 & 3,521 & 140 & 154 & 147,81 & 3,331 & 22,19 \\
\hline $\begin{array}{l}\text { Fruit } \\
\text { Control }\end{array}$ & 160 & 172 & 166,19 & 4,064 & 136 & 160 & 146,75 & 6,708 & 19,38 \\
\hline
\end{tabular}

TABLE V. BLOOD SUGAR LEVELS BEFORE AND AFTER DRINKING DRAGON FRUIT JUICE (N=32)

\begin{tabular}{|c|c|c|c|c|c|}
\hline Group & Perlakuan & $\mathrm{N}$ & Mean & SD & $\mathrm{p}$ value \\
\hline Dragon Fruit & Pretes & 16 & 170,00 & 3,521 & 0,000 \\
& Posttest & & 147,81 & 3,331 & \\
\hline Control & Pretes & 16 & 166,13 & 4,064 & 0,000 \\
& Posttest & & 146,75 & 6,708 & \\
\hline
\end{tabular}

The results there is an average decrease in respondents who consume dragon fruit. Another study explained that consumption of 200 gram of dragon fruit reduces glucose levels highest compared to others and the treatment can be most effective at reducing glucose levels Diabetes Melitus [5].

Dragon fruit contains a high amount of fiber and flavonoids. Fiber will slow down absorption of glucose and fat by increasing faecal viscosity which indirectly decreases the speed of diffusin so that blood glucose levels, lipid profiles and cholesterol decrease so that blood sugar levels are stable while antioxidants (flavonoids) work by maintaining blood vessel elasticity and improving the circulatory system [4]

TABEL VI. ANALYSIS OF DIFFERENCES IN BLOOD SUGAR LEVELS AFTER DRINK DRAGON FRUIT JUICE (N=32)

\begin{tabular}{|l|l|l|l|l|}
\hline Group & $\mathrm{N}$ & Mean & SD & p value \\
\hline Dragon Fruit & 16 & 22,19 & 4,230 & 0,061 \\
Control & 16 & 19,38 & 3,948 & \\
\hline
\end{tabular}

This research was conducted for 10 days every day and respondents still consume insulin. There is no difference in the blood sugar levels of the intervention group and the control group. Pharmacological and non-pharmacological therapies are equally needed by people with Diabetes Mellitus to regulate their blood sugar levelsto remain normal. Oral hypoglycemic drugs (OHO) are the main line treatment for type 2 Diabetes Melitus. These oral hypoglycemic drugs have also been effective in reducing high blood sugar levels, but complications caused by Diabetes Mellitus have not been prevented so efforts are still needed to find new drugs with physiological abilities that are right on target, safe and easily affordable [3]

Diabetic patient must also control their blood sugar in a disciplined manner through a healthy diet so that blood sugar does not rise above normal. The high amount of fiber in dragon fruit can help stabilize a person's blood sugar level. Fiber has the ability to slow the absorption of glucose and fat by increasing the viscosity of feses which indirectly reduces the speed of diffusion so that blood glucose levels, lipid profiles and cholesterol decrease. Red dragon fruit contains fiber and antioxidants that are beneficial for diabetics and cardiovascular patients. The content of dragon fruit fiber in the form of pectin has the ability to slow the absoption of glucose by increasing the thickness of the intestinal volume which has the potential to reduce the speed of diffusion so that glucose levels decrease. Dragon fruit contains phytochemicals that function as antioxidants that function to maintain the elasticity of blood vessels and cell permeability. Increased cell permeability will increase insulin sensitivity so that more blood glucose is carried by insulin into cells to be metabolized [5]. Another study that consume of dragon fruit prowder $>100$ grams for 1 month did not cause negative effects on the liver and kidneys. The control group in this study given a regular diet without consume of dragon fruit also experienced a significant decrease in blood glucose levels. these results indicate that the diet still plays an important role in maintaining glucose control.

\section{RESULT}

There was an average decrease in blood sugar levels in the tomato juice group by $20.50 \mathrm{~g} / \mathrm{dl}$ and dragon fruit juice by $22.19 \mathrm{~g} / \mathrm{dl}$. The two groups did not have differences in blood sugar levels with the control group.

\section{CONCLUSION}

Based on the results of the study, it was found that dragon fruit juice had no effect on the difference in reducing blood sugar levels with a $\mathrm{P}$ value of 0.061 . So it can be concluded that tomato juice and dragon fruit juice do not have a significant effect in reducing sugar levels. 


\section{REFERENCES}

[1] et al Smeltzer, BRUNNER \& SUDDARTH'S TEXTBOOK of Medical-Surgical Nursing. 2014.

[2] Kemenkes RI, "Hasil Utama Riset Kesehatan Dasar Tahun 2018," Kementrian Kesehat. Republik Indones., 2018.

[3] American Diabetes Association, "National Diabetes Statistics Report , 2014 Estimates of Diabetes and Its Burden in the Epidemiologic estimation methods," Natl. Diabetes Stat. Rep., 2014.

[4] A. R. Hidayati, "Pengaruh buah naga terhadap kadar glukosa darah pasien diabetes melitus tipe II di puskesmas temon 1 kulon progo yogyakarta," ilmu Kesehat., 2017.

[5] W. Komang, M. Yenny, and P. Sudita, "Jus Buah Naga Merah Menurunkan Kadar Glukosa Darah Penderita Dmt2," Politek. Kesehat. Denpasar, vol. 11, no. Dm, pp. 59-66, 2014.

[6] E. N. Story, R. E. Kopec, S. J. Schwartz, and G. K. Harris, “An Update on the Health Effects of Tomato Lycopene," Annu. Rev. Food Sci. Technol., vol. 1, no. 1, pp. 189-210, 2010.

[7] R. Chairunnisa, "Pengaruh Jumlah Pasta Tomat terhadap Penurunan Kadar Gula Darah pada Mencit Diabetes," J. Teknol. Ind. Pertan., 2012

[8] S. Agarwal and A. V. Rao, "Tomato lycopene and its role in human health and chronic diseases," Cmaj, vol. 163, no. 6, pp. 739-744, 2000.

[9] P. D. Sugiyono, metode penelitian kuantitatif, kualitatif,dan $R \& D$. 2016.

[10] S. Yulia, "Faktor-faktor yang mempengaruhi kepatuhan dalam menjalankan diet pada penderita diabetes mellitus tipe 2," Kesehat. Masy., 2015.

[11] A. Mu'nisa, "Analisis Kadar Likopen Dan Uji Aktivitas Antioksidan Pada Tomat Asal Sulawesi Selatan.," J. Bionature, 2012.

[12] I. W. A. Putra and K. N. Berawi, "Empat pilar penatalaksanaan pasien diabetes mellitus tipe 2," Majority, 2015.

[13] F. Eliana, "Penatalaksanaan DM Sesuai Konsensus Perkeni 2015," SATELIT Simp. 6.1 DM Updat. DAN Hb1C, 2015.

[14] M. T. Tahir, Yulistiani, and RAmiruddin, "Implementation of Pharmaceutical Care in Resolving Drug Problems in Type 2 Diabetes Mellitus," Folia Medica Indones., vol. 51, no. 2, pp. 80$85,2015$. 